\title{
Aeolian particle transport inferred using a $\sim 150$-year sediment record from Sayram Lake, arid northwest China
}

\author{
Long MA, ${ }^{1}$ Jinglu WU, ${ }^{2 *}$ Jilili ABUDUWAILI, ${ }^{1}$ Wen LIU ${ }^{1}$ \\ ${ }^{1}$ State Key Laboratory of Desert and Oasis Ecology, Xinjiang Institute of Ecology and Geography, Chinese Academy of Sciences, \\ Urumqi 830011, China; ${ }^{2}$ State Key Laboratory of Lake Science and Environment, Nanjing Institute of Geography and Limnology, \\ Chinese Academy of Sciences, Nanjing 210008, China \\ *Corresponding author: w.jinglu@niglas.ac.cn
}

\begin{abstract}
We studied sediment cores from Sayram Lake in the Tianshan Mountains of northwest China to evaluate variations in aeolian transport processes over the past 150 years. Using an end-member modeling algorithm of particle size data, we interpreted end members with a strong bimodal distribution as having been transported by aeolian processes, whereas other end members were interpreted to have been transported by fluvial processes. The aeolian fraction accounted for an average of $27 \%$ of the terrigenous components in the core. We used the ratio of aeolian to fluvial content in the Sayram Lake sediments as an index of past intensity of aeolian transport in the Tianshan Mountains. During the interval 1910-1930, the index was high, reflecting the fact that dry climate provided optimal conditions for aeolian dust transport. From 1930-1980, the intensity of aeolian transport was weak. From the 1980s to the 2000s, aeolian transport to Sayram Lake increased. Although climate in northwest China became more humid in the mid-1980s, human activity had by that time altered the impact of climate on the landscape, leading to enhanced surface erosion, which provided more transportable material for dust storms. Comparison of the Lake Sayram sediment record with sediment records from other lakes in the region indicates synchronous intervals of enhanced aeolian transport from 1910 to 1930 and 1980 to 2000.
\end{abstract}

Key words: Grain-size; aeolian; lake sediment; Tianshan Mountains, China.

Received: March 2015. Accepted: May 2015.

\section{INTRODUCTION}

In arid regions, climate variability and human land use influence dust production and aeolian transport (Derbyshire et al., 1998; O'Hara et al., 2000). In turn, dust particles are an important influence on climate and terrestrial biogeochemical cycles (Neff et al., 2008). Lake sediments are composed of autochthonous and allochthonous materials that provide information about past environmental change in the surrounding watershed. Sediment particle size has been use as a proxy for past environmental conditions because it is sensitive to climate change and is unaffected by biological activity (Asikainen et al., 2007; Chen et al., 2004; Peng et al., 2005; Qiang et al., 2007). Xiao et al. $(2012,2013)$ used a lognormal distribution function to investigate the relationship between the identity of constituent components and the specific depositional processes and sedimentary environment. Boulay et al. (2003) and Wan et al. (2007) identified intervals with the highest particle size variability in a sediment sequence from the South China Sea, by calculating the standard deviation of the particle size classes. Sun et al. (2002) estimated particle size components by fitting a defined function formula (Weibull function) to measured particle size data from samples, thereby achieving numerical partitioning of the sediment components. Weltje and Prins
(2007) and Dietze et al. (2012) used end-member mixing analysis of a data set to derive quantitative and geo-scientifically meaningful end members (EMs), which represent a series of fixed compositions that can be regarded as distinct subpopulations within the analysed data set.

The Tianshan Mountains provide source waters for the main rivers of Central Asia. The mountains extend over $2500 \mathrm{~km}$, from Tashkent, Uzbekistan, eastward into the Chinese province of Xinjiang (Zhao et al., 2009). Sayram is a closed-basin lake in the western Tianshan Mountains of northwest China. Given its basin structure and location, Sayram Lake possesses a high-quality sediment archive that can be utilized to increase our understanding of past climate and environmental change. The Sayram Lake sediment record was used to evaluate anthropogenic metal accumulations and quantify the human contribution to heavy metal pollution in the water body (Zeng et al., 2014). Liu et al. (2014) used multiple sediment variables, including geochemical composition, carbonate content, magnetic susceptibility, and $\delta^{13} \mathrm{C}$ and $\delta^{18} \mathrm{O}$ of bulk carbonate, to infer regional environmental change.

In this study, we applied an end-member modeling algorithm (Dietze et al., 2012) to separate the distributions of particle sizes in Sayram Lake sediments. Our objectives were to: i) quantify aeolian transport of material in the re- 
gion; and ii) identify general environmental patterns in the Tianshan Mountains over the past $\sim 150$ years. Data from this study have relevance for future management and protection of the watershed.

\section{METHODS}

\section{Regional setting}

Sayram Lake is located in the western part of the Tianshan Mountains, northwest China (Fig. 1). The lake surface area fluctuated between 458.6 and $462.2 \mathrm{~km}^{2}$ over the decade from 2001 to 2011 (Wu et al., 2014). The water body is surrounded by high mountains and has a catchment area of $1408 \mathrm{~km}^{2}$ (Wang and Dou, 1998). The vegetation of Sayram Lake Basin has relatively simple composition and obviously vertical bands. Above the $3800 \mathrm{~m}$ above sea level (asl), the surface is snow-covered region. From $3800 \mathrm{~m}$ to $2800 \mathrm{~m}$ asl, the vegetation changes from alpine sparse vegetation to alpine meadows. The surface is covered with subalpine steppe meadows (2800-2400 $\mathrm{m}$ asl). Then, the vegetation changes to forest meadows and mountain meadows (2400-2150 m asl). Around the lakeside belts, the vegetation varies to steppe and desert-steppe (Jin, 1995).

Lake Sayram has a maximum water depth of $99 \mathrm{~m}$ and an average water depth of $46.4 \mathrm{~m}$ (Wu et al., 2012). The lake is located in the hinterland of the Eurasian continent where Northern Hemisphere westerly winds are characteristic of the semi-arid climate. Water in Sayram Lake comes mainly from glacial snowmelt and phreatic water (Jin, 1995). There are 39 inflows around the lake. Among these, 7 rivers are perennial, 13 ones are spring-fed, and 19 ones are seasonal (Jin, 1995). The region receives annual total precipitation of $350 \mathrm{~mm}$, and mean annual temperature is about $0.5^{\circ} \mathrm{C}$ (Wang and Dou, 1998). Regional grasslands constitute a rich resource that is exploited by traditional Kazak herders. There are no residential villages and there is no agricultural cultivation around the lake. Nomadic grazing of livestock is the most important activity in the drainage basin.

\section{Methodology}

Sediment samples (R1, R2, R3, and R4) were collected from four seasonal rivers around the lake (Fig. 1). Due to restrictions of field conditions, there are great difficulties in collecting dust samples in Sayram Lake Basin. However, combined with our studies near the Sayram Lake Basin, dust collectors were used to trap aeolian dustfall samples (Fig. 1c). Traps, made of polyethylene cylinders with a diameter of $15 \mathrm{~cm}$ and depth of $30 \mathrm{~cm}$, were vertically fitted on platforms about $3 \mathrm{~m}$ above the ground. The dust was directly fall into the open cylinder, and was collected six months later.

Two parallel sediment cores were collected in January
2013 (Fig. 1) using a piston-percussion corer (Reasoner, 1993) fitted with 60-mm-internal-diameter Perspex tubes. The lake cores were extruded vertically in the field, and were sampled at $0.5-\mathrm{cm}$ intervals. Each core sample was sealed in a labeled plastic bag. One core $(30 \mathrm{~cm}$ long) was obtained for dating and the other $(23 \mathrm{~cm}$ long) for particle size analysis. The yellow-brown sediment cores did not have obvious laminations. The sediment samples were dried at $-50^{\circ} \mathrm{C}$ in a freeze-drying machine. The content of total organic carbon (TOC) was determined by oxidation with potassium dichromate (Walkley and Black, 1934). Carbonate content was determined by the volumetric calcimeter method as described in Loeppert and Suarez (1996), and the error in carbonate measurement was less than 5\%. Magnetic susceptibility (MS) was measured in the laboratory with a Bartington MS2 susceptibility meter (Bartington Instruments, Oxford, England).

Sub-samples of dried sediment from the $30-\mathrm{cm}$ core were analyzed for ${ }^{210} \mathrm{~Pb},{ }^{226} \mathrm{Ra}\left({ }^{214} \mathrm{~Pb}\right.$ and $\left.{ }^{214} \mathrm{Bi}\right)$ and ${ }^{137} \mathrm{Cs}$ activity by direct gamma spectrometry, using an Ortec HPGe GWL series, well-type, coaxial, low-background intrinsic germanium detector (Appleby et al., 1986) at State Key Laboratory of Lake Science and Environment, Chinese Academy of Sciences. Supported ${ }^{210} \mathrm{~Pb}$ in each sample was assumed to be in equilibrium with in situ ${ }^{226} \mathrm{Ra}$. Unsupported ${ }^{210} \mathrm{~Pb}$ activity $\left({ }^{210} \mathrm{~Pb}\right.$ ex $)$ at each depth was calculated by subtracting ${ }^{226} \mathrm{Ra}$ activity from total ${ }^{210} \mathrm{~Pb}$ activity. Age-depth relations and sediment accumulation rates were calculated using the constant rate of supply (CRS) model (Appleby and Oldfield 1983).

Samples were pre-treated with $10-20 \mathrm{~mL}$ of $30 \% \mathrm{H}_{2} \mathrm{O}_{2}$ to remove organic matter and with $10 \mathrm{ml}$ of $10 \% \mathrm{HCl}$ to remove carbonates, prior to particle size analysis. Approximately $2 \mathrm{~L}$ of deionized water was added and the sample was held for $24 \mathrm{~h}$ to remove the acid. Sample residue was treated with $10 \mathrm{ml}$ of $0.05 \mathrm{M}\left(\mathrm{NaPO}_{3}\right)_{6}$ and placed on an ultrasonic vibrator for $10 \mathrm{~min}$ to facilitate dispersion before particle size analysis. Particle size distribution was determined with a Malvern Mastersizer 2000 analyser with a measurement range of 0.02-2000 $\mu \mathrm{m}$. The Mastersizer 2000 automatically determines median diameter and size fractions with a measurement precision $<1 \%$. The analysis was conducted at the State Key Laboratory of Lake Science and Environment, Chinese Academy of Sciences.

From the traditional explanation of grain size-distribution, the coarser or finer grain-size indicated the hydrodynamic environments of lake and river flow in humid region (Chen et al., 2004). However, in the lakes of arid China, the terrigenous masteries blowing by wind are also the major sources of lake sediment. If we only detected the paleo-environmental change from grain-size distribution along the depth (e.g., Fig. 2), we would just believe that the material source are only from one geologic force (e.g., hydrodynamic force). It will cover up the real scene. 


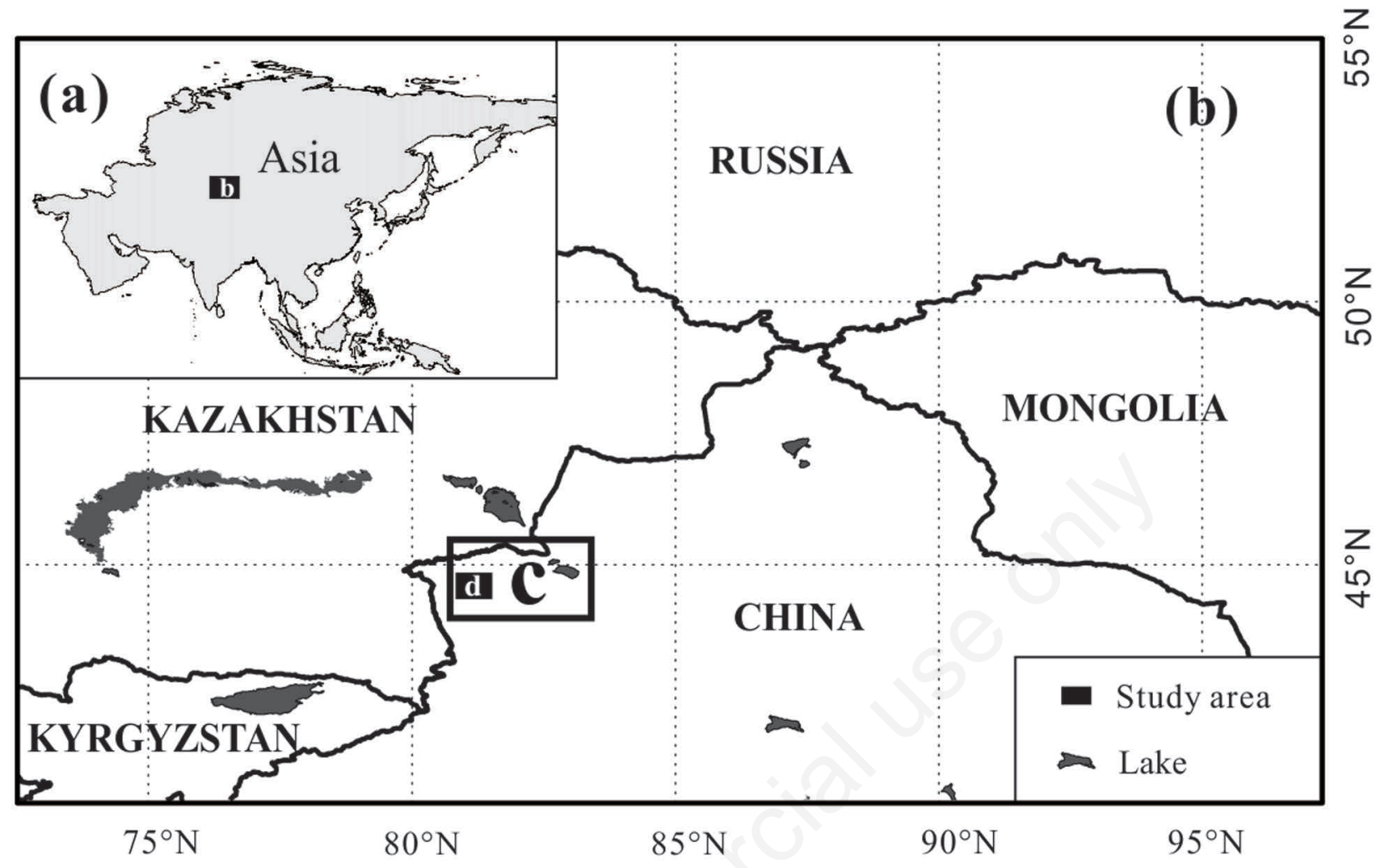

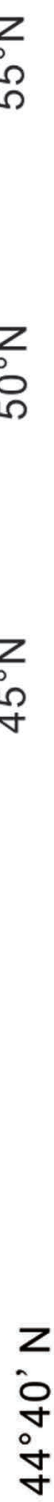

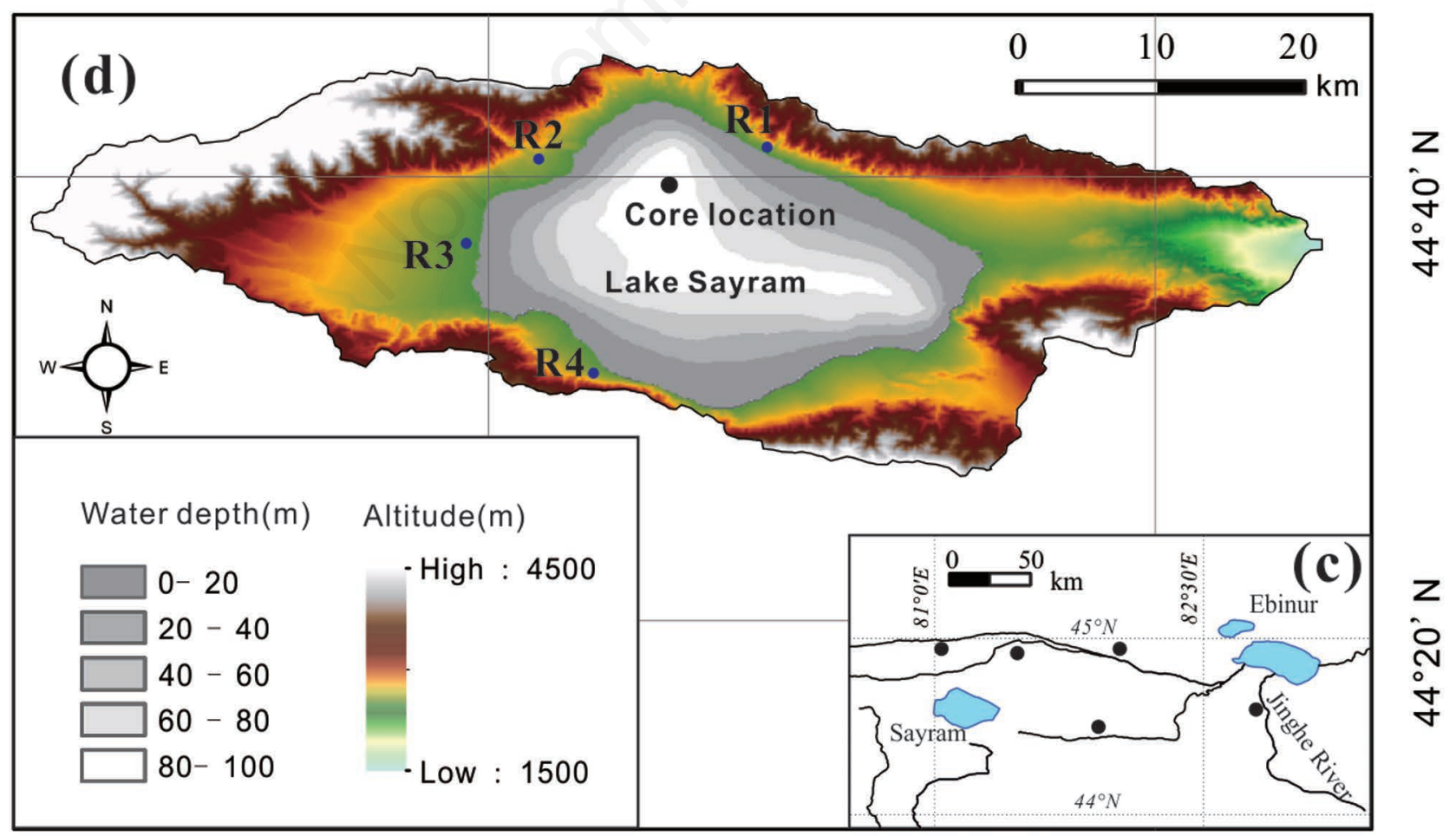

Fig. 1. a, b) Geographic location and bathymetry of Sayram Lake. c) Sites of dustfall samples. d) Sites of riverine samples collection. 
Therefore, mathematical methods for arid and semi-arid lake sediments (Chen et al., 2013; Qiang et al., 2014; Xiao et al., 2012, 2013) were taken to track the depositional processes and sedimentary environments.

In this study, the total set of particle size measurements from Sayram Lake was calculated using the endmember algorithm (Dietze et al., 2012). End-member analysis has been widely used to handle the original data set to derive quantitative and geo-scientifically meaningful end members. The minimum number of end members (EMs) required for a satisfactory approximation of the data is determined by not only the explained cumulative variance but also the coefficient of determination $\left(\mathrm{R}^{2}\right)$ for each size class and sample depth that can be reproduced by the grain-size distribution of the approximated end members.

\section{RESULTS}

\section{Age-depth relations in the sediments}

The excess ${ }^{210} \mathrm{~Pb}\left({ }^{210} \mathrm{~Pb}_{\mathrm{ex}}\right)$ and ${ }^{137} \mathrm{Cs}$ profiles in the sediment core are shown in Fig. 3a. The ${ }^{137} \mathrm{Cs}$ activity first appears at $12 \mathrm{~cm}$, which was assigned a date of AD 1954 (Appleby et al., 1997; Blais et al., 1995). The ${ }^{137}$ Cs peak at $7.5 \mathrm{~cm}$ recorded the 1963 fallout maximum from atmospheric nuclear testing (Miller and Heit, 1986). The CRS model yielded dates of 1955 at $12.0 \mathrm{~cm}$ and 1968 at $9.5 \mathrm{~cm}$. The ${ }^{210} \mathrm{~Pb}$ dates are in general agreement with the
${ }^{137} \mathrm{Cs}$ dates. The CRS model yielded dates of AD 1870 at $23 \mathrm{~cm}$ depth and AD 1880 at $22 \mathrm{~cm}$ depth.

\section{Particle size distribution in the core sediments}

Sediment mass was 3-7\% total organic carbon and 27$43 \%$ carbonate (as $\mathrm{CaCO}_{3}$ ), and was dominated by clay and silty clay. Particles were coarsest in surface sediment $(\sim 0$ $4 \mathrm{~cm}$ depth) and in the middle layers, in the interval from 10 to $15 \mathrm{~cm}$. The particle size distribution data, and values for median particle size (Md), mean particle size (Ms), and standard deviation (SD) of particle sizes (Peng et al., 2005) for Sayram Lake sediments are presented in Fig. 2. The sand $(>64 \mu \mathrm{m})$, silt $(4-64 \mu \mathrm{m})$ and clay $(<4 \mu \mathrm{m})$ fractions accounted for $10.2 \%, 75.5 \%$ and $14.3 \%$ of the sediment, respectively. The clay-size fraction is lowest at a depth of $\sim 12 \mathrm{~cm}$, but is generally higher both above and below that depth. The sand fraction is negatively correlated $(\mathrm{r}=-0.59$, $\mathrm{P}<0.01$ ) with the concentration of the clay fraction, but positively correlated with mean particle size $(\mathrm{r}=0.91, \mathrm{P}<0.01)$ and median particle size $(\mathrm{r}=0.81, \mathrm{P}<0.01)$.

The particle size distributions of the Sayram Lake sediments were shown in Fig. 3b. Sediment particle sizes in the Sayram Lake core spanned from 0.4 to $725 \mu \mathrm{m}$, and particle sizes in the range $15-30 \mu \mathrm{m}$ had the highest frequency. In general, particle size of representative samples with higher coarser contents have bimodal distribution pattern (Fig. 3c).

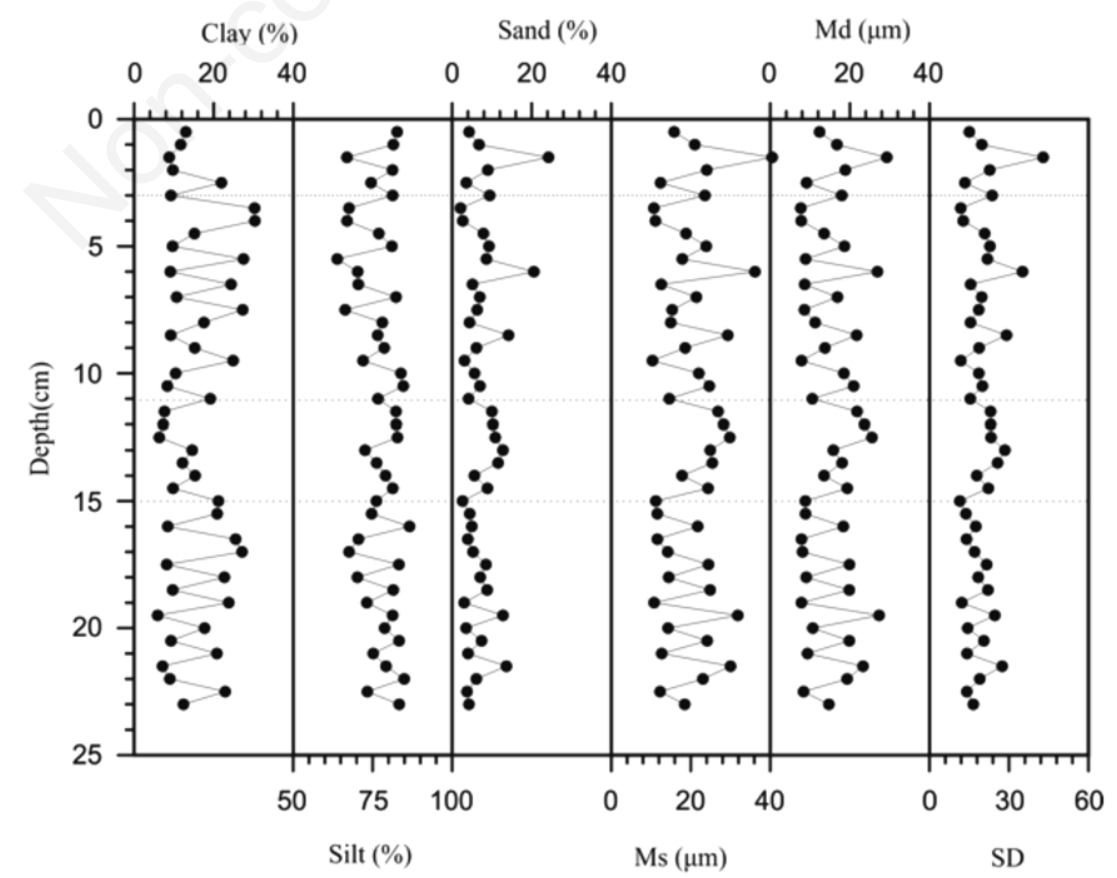

Fig. 2. Particle size distribution in Sayram Lake sediments. Ms, mean size; Md, median size. 


\section{End-member modeling for particle size distribution}

Sediments with a polymodal distribution have been mathematically proven to be the sum of all sediment components, and different transport and deposition processes can be recognized based on end-member analysis (Dietze et al., 2012). Hence, classical particle-size parameters, such as those presented above, are mathematically insufficient to describe the polymodal structure in particle size data sets. Results of end-member analysis are shown in Fig. 4, and Supplementary Figs. 1 and 2. The mean coefficient of determination of particle size increased when the number of end-members increased (Fig. 4a). A fiveend-member model explained $99 \%$ of the variance in the particle size distribution (Fig. 4a). The coefficient of determination $\left(\mathrm{R}^{2}\right)$ is plotted against sediment depth and particle size in Fig. 4 b,c, respectively. The five-end-member model showed goodness-of-fit statistics for particle size classes (mean $\mathrm{R}^{2}=0.81$ ) and sediment samples at different depths (mean $\mathrm{R}^{2}=0.89$ ). This indicates that the majority of the data are well represented by the model. Goodnessof-fit statistics did not improve significantly when more end members were used. Therefore, the five-end-member model was optimal.

The down-core record of relative end-member contributions is shown in Fig. 4c. End members 1 to 5 repre- sented on average $4 \%, 5 \%, 22 \%, 36 \%$ and $33 \%$ of the total sediment composition, respectively (Fig. 4d). Particle size distributions of the five end members are shown in Fig. 5. EM1 is poorly sorted and has three prominent peaks, at 2, 23 and $417 \mu \mathrm{m}$. EM2 and EM3 have bimodal distributions. Although the minor modes may be from orthogonal and linearity constraints in end-member algorithm (Dietze et al., 2014), secondary modes were not ignored with respect to their weight coefficients. The EM2 fraction has peaks at 7 and $120 \mu \mathrm{m}$, and the latter was the dominant mode. The EM3 fraction has a bimodal particle size, with peaks at $4 \mu \mathrm{m}$ and $60 \mu \mathrm{m}$, and the former was the dominant mode. EM4 has a unimodal particle size distribution with a mode of $11 \mu \mathrm{m}$, and EM5 also has a unimodal particle size distribution, with a mode of $35 \mu \mathrm{m}$. River samples showed two modes, one about $10 \mu \mathrm{m}$ and the other about $100 \mu \mathrm{m}$.

\section{DISCUSSION}

There are some multi-modal end members in the results that show two aspects. One is that the unmixing of the particle size distributions using the end-member modeling was incomplete, and the other is that end members in fact have multi-modal patterns. Results are constrained by mathematical algorithms and results thus have some
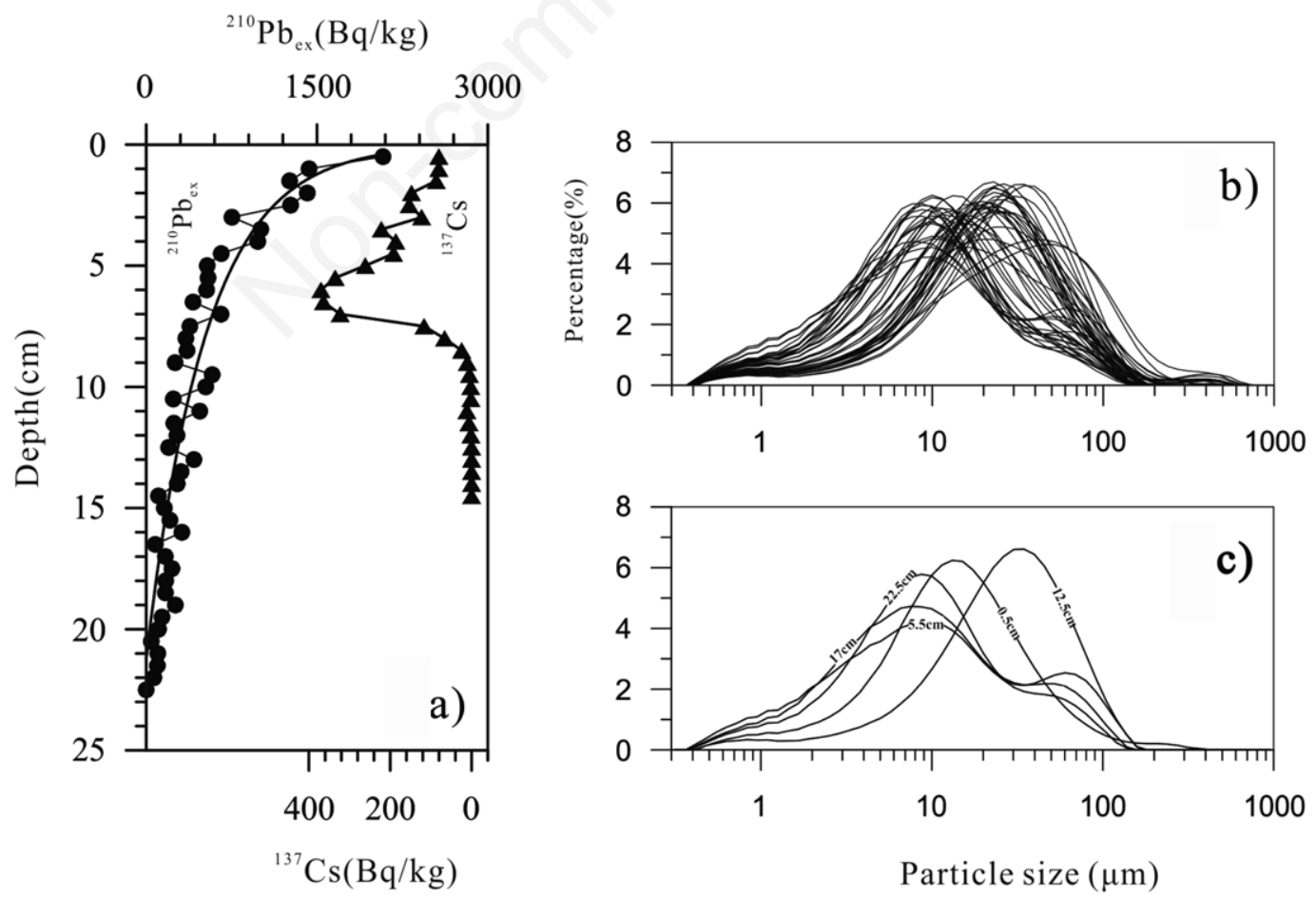

Fig. 3. a) Vertical distribution of excess ${ }^{210} \mathrm{~Pb}\left({ }^{210} \mathrm{~Pb}_{\mathrm{ex}}\right)$ and ${ }^{137} \mathrm{Cs}$ activity in the Sayram Lake sediment core. b) The particle size distributions in the Sayram Lake core. c) Particle-size distributions of the representative samples. 
shortcomings, which will require new or modified methods to handle the mixed data sets. Particle-size distribution patterns are related to manner of transportation and environment of deposition (Xiao et al., 2012). The frequency curve of particle-size distribution produced in one sedimentation or transportation process is usually unimodal, whilst the involvement of more than one sedimentation or transportation process in sediment formation may yield a polymodal distribution (Liu et al., 2009).

EM1 was poorly sorted (Fig. 5a), with three prominent modes. Multimodal EM1 is likely an example of glacially supplied material (Weltje and Prins, 2007; Liu et al., 2009). Because the mean contribution of EM1 was $<4 \%$ of the total sediment, we excluded EM1 from further analysis. EM2 and EM3 have bimodal distributions (Fig. $5 \mathrm{a}, \mathrm{c})$. The grain-size distribution of modern dust, which is a mixture of coarse-grained event dust and fine-grained background dust (Sun, 2004), will be have bimodal distribution. The bimodal distribution of aeolian dust in our study may be attributed to mixture of local and remote suspended terrigenous material. Local material is associated with rolling and saltation, induced by strong surface
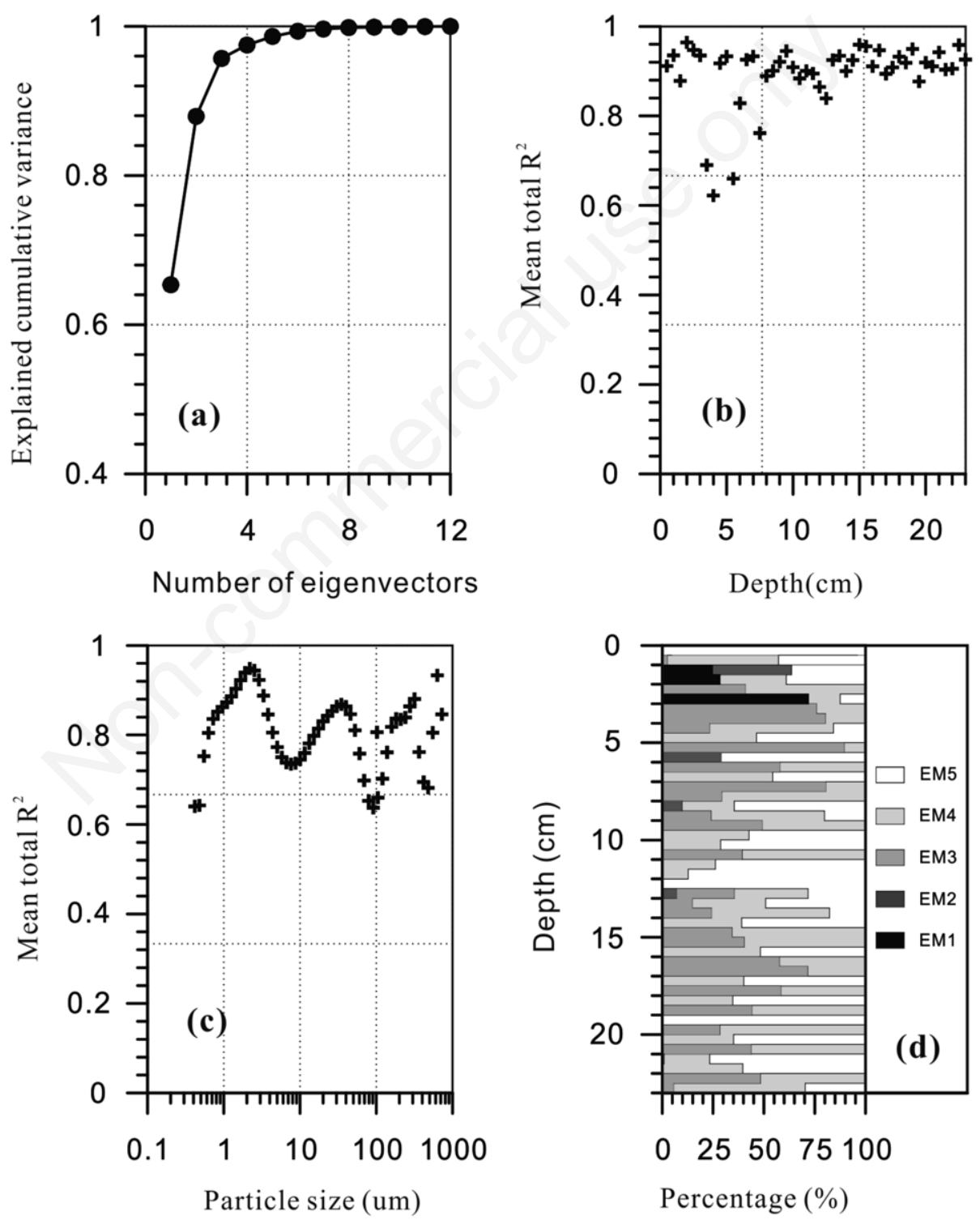

Fig. 4. End-member modeling results for the Sayram Lake sediment core. a) Mean coefficient of determination ( $\mathrm{R}^{2}$ mean) of all size classes for each end-member model. b) Coefficients of determination $\left(\mathrm{R}^{2}\right)$ for sediment samples with five end members. c) Coefficients of determination for each size class of the model with five end members. d) End-member scores (\%) show the proportion of variance explained by five end members for each sediment sample. 
winds (Dietze et al., 2014). EM2 is coarser than EM3, which indicates a different transport energy. Stronger winds and/or shorter transport pathways result in greater transport of coarse-grained dust to Sayram Lake. Windblown sediment, however, is generally well-sorted and typical aeolian material is unimodal (Prins et al., 2007; Nottebaum et al., 2014; Xiao et al., 2013). In this case, however, particles have different patterns in the dominant modes for source area conditions and transport height and distance (Vandenberghe, 2013). Thus, the combination of different dust transport processes leads to a bimodal distribution, which can be supported by our collected dusfall samples. Although one dust transport process will result that frequency distribution curve of modern eolian dust have narrow bimodal distribution, the mixture of multiple dust events will also lead to multimodal pattern (Fig. 5c). EM4 and EM5 (Fig. 5b) have well-sorted sediments among the five end members. Although the rivers around the lake have different carrying capacities, which accounts for the different distribution patterns of the surface sample particle sizes collected around the lake (Fig. 5d), the grain-size distributions of the four surface samples have unimodal patterns. Differences in hydrodynamics were responsible for the different dominant modes in the four river sediment samples taken around the lake. The terrigenous fraction of particle sizes that originate from strong rivers will be coarser. Particle size in EM5 is coarser than that in EM4, which indicates that the hydrodynamic forces that affected EM5 were stronger than those that affected EM4. The total content of EM4 and EM5 can be viewed as an indication of the regional hydrodynamic processes, which have the generally consistent trend with the variations in annual stream flow of Jinghe River (Shang et al., 2014), near Sayram Lake (Fig. 6).

In this study, the ratio of aeolian (EM2+EM3) to fluvial end members (EM4+EM5) was used as an indicator for the intensity of aeolian transport. From 1910 to 1930 and from 1980 to 2000 (Fig. 6), the proportion of aeolian material varied considerably because of intense dust storms. Those two periods were influenced strongly by aeolian conditions, and coincide with periods of strong aeolian transport at Chaiwopu Lake (Fig. 6) (Ma et al., 2013), which were also dated to the intervals 1910-1930 and 1980-2000. Apparent synchrony of dust storms in western China is best explained by regional forcing mechanisms. Regional climate was generally dry, but experienced strong oscillations from $c a .1910$ to the 1930s in agreement with Chaiwopu Lake region inferred from or- a)

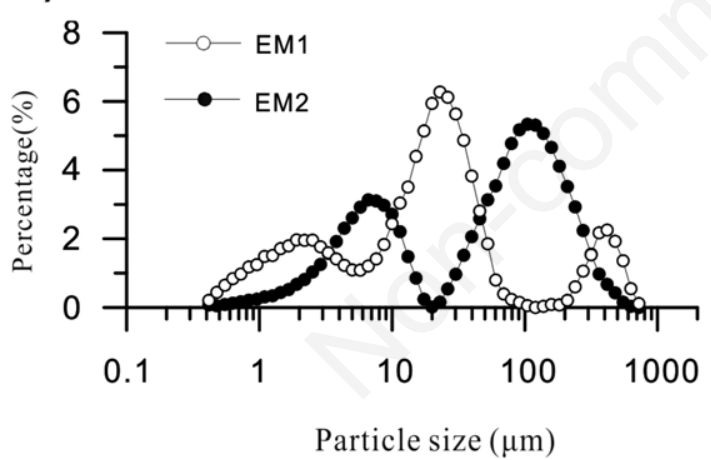

c)

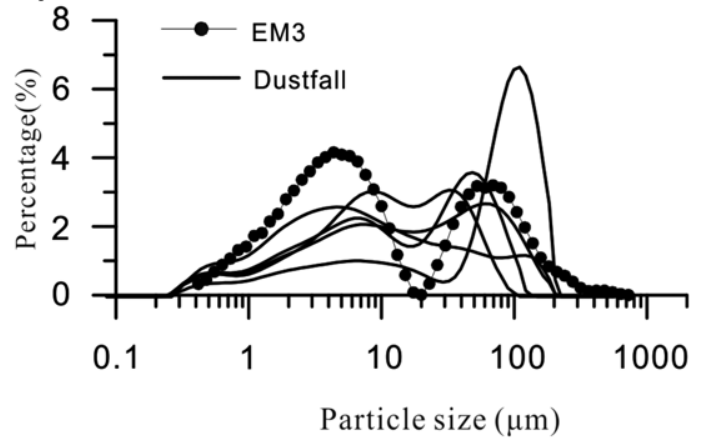

b)

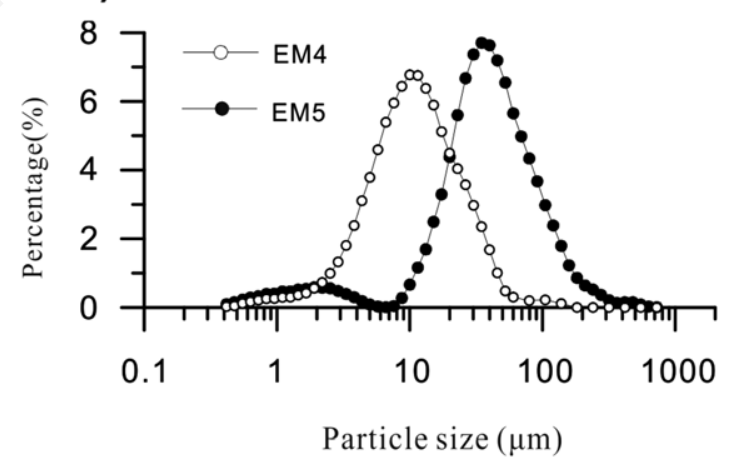

d)

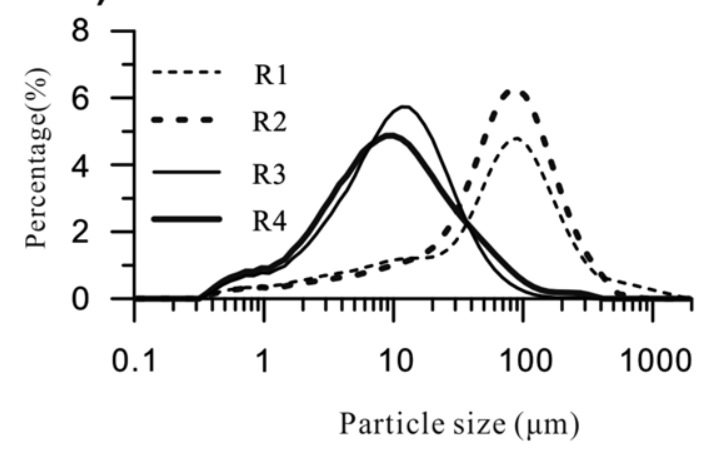

Fig. 5. Modelled end-members of the terrigenous sediment fraction from Sayram Lake. a) Particle size distribution of EM1 and EM2. b) Particle size distribution of EM4 and EM5. c) Particle size distribution of EM3 with dustfall samples. d) Particle size distributions of surface samples taken near the lakeshore are presented for comparison. 
ganic matter and its stable isotope $\left({ }^{13} \mathrm{C}\right)$ in the lacustrine records (Ma et al., 2013). These conditions provided enhanced source material for aeolian transport. Meteorological data indicate increased temperature and precipitation during the past 50 years in the Sayram Lake region (Shi et al., 2007), but human activities reduced the influence of wetter climate on surface soils. Magnetic minerals in lake sediment come mainly from surface material in the watershed. Higher values of magnetic susceptibility over the past few decades (Fig. 6) indicate greater erosion in the lake drainage basin, caused by human activity $(\mathrm{Hu}$, 2002). Widespread deforestation in the 1970s also opened the landscape and induced greater soil erosion. Similarly, overgrazing during the 1980s (Jin, 1995) increased land surface erosion. According to the Eco-environment Protection Program in Lake Sayram Basin (2012-2016) (http://www.xjboz.gov.cn), raised by the government of Boertala Mongolia Autonomous Region, Xinjiang, China, inside the summer pasture area of 1.11 million mu (China unit of area; $15 \mathrm{mu}=1 \mathrm{ha}), 62.8 \%$ of pasture area are destroyed and undergo degeneration. The phenomena of vegetation degradation, surface exposed and desertification are occurred in lakeside belts, and the desertification area has reached 250 hectares. We conclude that human

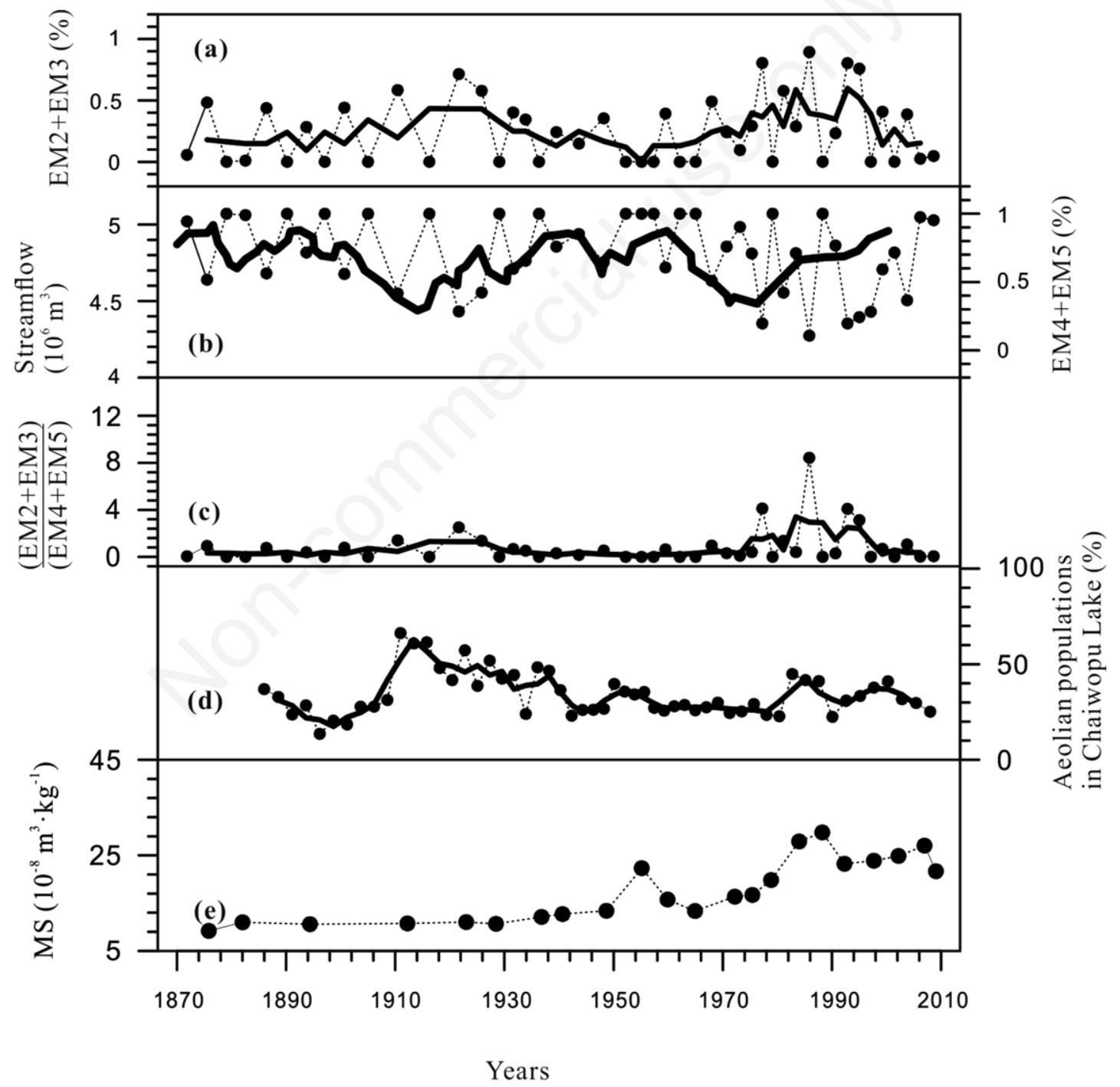

Fig. 6. Regional proxies for fluvial and aeolian environments. a) Relative content of aeolian transported material (EM2+EM3) in Sayram Lake sediments (dashed line) with the three-point running average (solid line). b) Relative content of fluvial transported material (EM4+EM5) in Sayram Lake sediments (dashed line) comparing with annual streamflow of Jinghe River (Shang et al., 2014) (solid line). c) Ratio of aeolian to fluvial transport fractions in the Sayram Lake core. d) Content of aeolian particle size populations recovered from the Chaiwopu Lake core (Ma et al., 2013). e) Magnetic susceptibility (MS) of Sayram Lake sediments. 
activity over the past 50 years provided abundant material for dust storm generation.

Wind is the main factor for dust and sand deflation and transport (Liu et al., 2004). The Arctic Oscillation (AO) increased and was in a positive phase during the periods 1910-1930 and 1980-2000 (Moritz et al., 2002). This helped the middle latitude jet stream to blow strongly and consistently from west to east, and consequently, westerly winds were stronger than normal over the northern Eurasian Continent (Sun et al., 2001). A strong westerly jet stream in the upper troposphere is linked to generation of cyclones and fronts at lower atmospheric levels. In turn, these may cause strong winds that lead to increased dust storm activity in the region, resulting in coarser particle size fractions being deposited in the lake.

\section{CONCLUSIONS}

Sayram Lake is located in the Tianshan Mountains of northwest China, where climate is dominated by Northern Hemisphere westerly winds. Lake sediment particle size is a conventional proxy for investigating past aeolian particle transport because it is sensitive to climate and unaffected by biological activity. An end-member modeling algorithm allowed us to distinguish the different sedimentological components in the Sayram Lake sediments, thereby providing insights into aeolian activity in this region over the past $\sim 150$ years.

Sayram Lake sediments are composed of aeolian and fluvial material that accounts for $27 \%$ and $69 \%$ of the total terrigenous sediment, respectively. The intensity of fluvial sediment transport had the generally consistent trend with the variations in annual stream flow of Jinghe River. Aeolian deposition was relatively stronger during the intervals 1910-1930 and 1980-2000, periods when fluvial inputs were relatively low. The strong aeolian conditions during 1910-1930 and 1980-2000 coincided with periods of such strong wind transport inferred from the sediment record of Chaiwopu Lake in the central Tianshan Mountains (Ma et al., 2013). Apparent synchrony of dust storms in western China is explained by regional forcing mechanisms.

This study used grain-size data to distinguish aeolian from fluvial fractions in a lake sediment sequence from northwest China. Future work will combine the grain-size algorithm with other lake sediment variables, such as elemental data and mineral assemblages, to better distinguish sediment sources.

\section{ACKNOWLEDGEMENTS}

The authors wish to thank Mark Brenner, the anonymous reviewers and the editors for their helpful comments and suggestions, which improved the manuscript. This study was supported by the National Natural Science
Foundation of China (41471173; U1138301), National Basic Research Program of China (2012CB956102). The authors also gratefully acknowledge the support of the Youth Innovation Promotion Association (CAS).

\section{REFERENCES}

Appleby P, Oldfield F, 1983. The assessment of ${ }^{210} \mathrm{~Pb}$ data from sites with varying sediment accumulation rates. J. Paleolimnol. 103:29-35.

Appleby P, Shotyk W, Fankhauser A, 1997. Lead-210 age dating of three peat cores in the Jura Mountains Switzerland. Water Air Soil Poll. 100:223-231.

Appleby PG, Nolan PJ, Gifford DW, Godfrey MJ, Oldfield F, Anderson NJ, Battarbee RW, 1986. ${ }^{210} \mathrm{~Pb}$ dating by low background gamma counting. Hydrobiologia 143:21-27.

Asikainen CA, Francus P, Brigham-Grette J, 2007. Sedimentology clay mineralogy and grain-size as indicators of $65 \mathrm{ka}$ of climate change from El'gygytgyn Crater Lake Northeastern Siberia. J. Paleolimnol. 37:105-122.

Blais JM, Kalff J, Cornett RJ, Evans RD, 1995. Evaluation of ${ }^{210} \mathrm{~Pb}$ dating in lake sediments using stable $\mathrm{Pb}$, Ambrosia pollen, and 137Cs. J. Paleolimnol. 13:169-178.

Boulay S, Colin C, Trentesaux A, Pluquet F, Bertaux J, Blamart D, Buehring C Wang P, 2003. Mineralogy and sedimentology of Pleistocene sediment in the South China Sea (ODP Site 1144), p.1-21. In: W.L. Prell, P. Wang, P. Blum, D.K. Rea and S.C. Clemens (eds.) Proc. Ocean Drilling Program Scientific Results 184. Available from: http://www-odp.tamu.edu/publications/184_SR/VOLUME/CHAPTERS/211.PDF

Chen F, Qiang M, Zhou A, Xiao S, Chen J, Sun D, 2013. A 2000year dust storm record from Lake Sugan in the dust source area of arid China. J. Geophys. Res. Atmos 118:2149-2160.

Chen J, Wan G, Zhang D, Zhang F Huang R, 2004. Environmental records of lacustrine sediments in different time scales: sediment grain size as an example. Sci. China Ser. D 47:954-960.

Derbyshire E, Meng X, Kemp RA, 1998. Provenance transport and characteristics of modern aeolian dust in western Gansu Province China and interpretation of the Quaternary loess record. J. Arid Environ 39:497-516.

Dietze E, Hartmann K, Diekmann B, IJmker J, Lehmkuhl F, Opitz S, Stauch G, Wünnemann B, Borchers A, 2012. An end-member algorithm for deciphering modern detrital processes from lake sediments of Lake Donggi Cona, NE Tibetan Plateau China. Sediment. Geol. 243:169-180.

Dietze E, Maussion F, Ahlborn M, Diekmann B, Hartmann K, Henkel K, Kasper T, Lockot G, Opitz S, Haberzettl T, 2014. Sediment transport processes across the Tibetan Plateau inferred from robust grain-size end members in lake sediments. Clim. Past 10:91-106.

$\mathrm{Hu} \mathrm{S}, 2002$. Identification of greigite in lake sediments and its magnetic significance. Sci. China Ser. D 45:81-87.

Jin X, 1995. [Lakes in China: research of their environment. 2].[Book in Chinese]. China Ocean Press, Beijing: 668 pp.

Liu W, Wu J, Ma L, Zeng H, 2014. A 200-year sediment record of environmental change from Lake Sayram, Tianshan Mountains in China. GFF 136:548-555.

Liu X, Dong H, Yang X, Herzschuh U, Zhang E, Stuut J-BW, Wang Y, 2009. Late Holocene forcing of the Asian winter 
and summer monsoon as evidenced by proxy records from the northern Qinghai-Tibetan Plateau. Earth Planet. Sci. Lett. 280:276-284.

Liu X, Yin Z, Zhang X, Yang X, 2004. Analyses of the spring dust storm frequency of northern China in relation to antecedent and concurrent wind precipitation vegetation and soil moisture conditions. J. Geophys. Res. 109: D16210.

Loeppert RH, Suarez D, 1996. Carbonate and gypsum, p. $457-$ 604. In D.L. Sparks (ed.), Methods of soil analysis, Part 3. Chemical Methods, SSSA and ASA, Madison.

Ma L, Wu J, Abuduwaili J, 2013. Climate and environmental changes over the past 150 years inferred from the sediments of Chaiwopu Lake central Tianshan Mountains northwest China. Int. J. Earth Sci. 102:959-967.

Miller KM, Heit M, 1986. A time resolution methodology for assessing the quality of lake sediment cores that are dated by ${ }^{137}$ Cs. Limnol. Oceanogr. 31:1292-1300.

Moritz RE, Bitz CM, Steig EJ, 2002. Dynamics of recent climate change in the Arctic. Science 297:1497-1502.

Neff J, Ballantyne A, Farmer G, Mahowald N, Conroy J, Landry C, Overpeck J, Painter T, Lawrence C, Reynolds R, 2008. Increasing eolian dust deposition in the western United States linked to human activity. Nature Geosci. 1:189-195.

Nottebaum V, Lehmkuhl F, Stauch G, Hartmann K, Wünnemann B, Schimpf S, Lu H, 2014. Regional grain size variations in aeolian sediments along the transition between Tibetan highlands and north-western Chinese deserts-the influence of geomorphological settings on aeolian transport pathways. Earth Surf. Proc. Land. 39:1960-1978.

O'Hara SL, Wiggs GF, Mamedov B, Davidson G, Hubbard RB, 2000. Exposure to airborne dust contaminated with pesticide in the Aral Sea region. Lancet 355:627-628.

Peng Y, Xiao J, Nakamura T, Liu B, Inouchi, Y, 2005. Holocene East Asian monsoonal precipitation pattern revealed by grain-size distribution of core sediments of Daihai Lake in Inner Mongolia of north-central China. Earth Planet. Sci. Lett. 233:467-479.

Prins MA, Vriend M, Nugteren G, Vandenberghe J, Lu H, Zheng H, Weltje GJ, 2007. Late Quaternary aeolian dust input variability on the Chinese Loess Plateau: inferences from unmixing of loess grain-size records. Quarter. Sci. Rev. 26:230-242.

Qiang M, Liu Y, Jin Y, Song L, Huang X, Chen F, 2014. Holocene record of eolian activity from Genggahai Lake, northeastern Qinghai-Tibetan Plateau, China. Geophys. Res. Lett. 41:589-595.

Qiang M, Chen F, Zhang J, Zu R, Jin M, Zhou A Xiao S, 2007. Grain size in sediments from Lake Sugan. a possible linkage to dust storm events at the northern margin of the QinghaiTibetan Plateau. Environ. Geol. 51:1229-1238.

Reasoner MA, 1993. Equipment and procedure improvements for a lightweight inexpensive percussion core sampling system. J. Paleolimnol. 8:273-281.
Shang H, Yin Z, Chen Z, Wei W, Yuan Y, Chen R, 2014. [Annual streamflow of Jinghe River Basin in northern slope of Tianshan Mountains recorded by tree ring during 16152007].[Article in Chinese with English Abstract]. Adv. Water Sci. 25:779-788.

Shi Y, Shen Y, Kang E, Li D, Ding Y, Zhang G, Hu R, 2007. Recent and future climate change in northwest China. Climatic Change 80:379-393.

Sun D, 2004. Monsoon and westerly circulation changes recorded in the late Cenozoic aeolian sequences of Northern China. Global Planet. Change 41:63-80.

Sun D, Bloemendal J, Rea D, Vandenberghe J, Jiang F, An Z, $\mathrm{Su}$ R, 2002. Grain-size distribution function of polymodal sediments in hydraulic and aeolian environments and numerical partitioning of the sedimentary components. Sediment. Geol. 152:263-277.

Sun J, Zhang M, Liu T, 2001. Spatial and temporal characteristics of dust storms in China and its surrounding regions 1960-1999. Relations to source area and climate. J. Geophys. Res. 106:10325-10333.

Vandenberghe J, 2013. Grain size of fine-grained windblown sediment: a powerful proxy for process identification. Earth Sci. Rev. 121:18-30.

Walkley A, Black IA, 1934. An examination of the Degtjareff method for determining soil organic matter, and a proposed modification of the chromic acid titration method. Soil Sci. 37:29-38.

Wan S, Li A, Jan-Berend WS, Xu F, 2007. Grain-size records at ODP Site 1146 from the northern South China Sea. Implications on the East Asian monsoon evolution since $20 \mathrm{Ma}$. Sci. China Ser. D 50:1536-1547.

Wang S, Dou H,1998. [Lakes in China].[Book in Chinese]. Science Press, Beijing: 580 pp.

Weltje GJ, Prins MA, 2007. Genetically meaningful decomposition of grain-size distributions. Sediment. Geol. 202:409424.

Wu J, Liu W, Zeng H, Ma L, Bai R, 2014. Water quantity and quality of six lakes in the arid Xinjiang Region, NW China. Environ. Proc. 1:115-125.

Xiao J, Chang Z, Fan J, Zhou L, Zhai D, Wen R, Qin X, 2012. The link between grain-size components and depositional processes in a modern clastic lake. Sedimentology 59:10501062.

Xiao J, Fan J, Zhou L, Zhai D, Wen R, Qin X, 2013. A model for linking grain-size component to lake level status of a modern clastic lake. J. Asian Earth Sci. 69:149-158.

Zeng H, Wu J, Liu W, 2014. Two-century sedimentary record of heavy metal pollution from Lake Sayram: A deep mountain lake in central Tianshan, China. Quatern. Int. 321:125-131.

Zhao J, Liu S, He Y, Song Y, 2009. Quaternary glacial chronology of the Ateaoyinake River Valley, Tianshan Mountains, China. Geomorphology 103:276-284. 